\title{
Analisis Kinerja Keuangan PT. Garuda Food Tbk periode 2017-2019
}

\author{
Ina Baiti \\ Universitas Bina Darma \\ Email: inabaiti13@gmail.com
}

\begin{abstract}
The purpose of this research is to know the financial performance of PT. Garudafood, Tbk period 20172019. The type of research used is associative research. The population in this study is a record of the financial statements of PT. Garudafood, Tbk, period 2017-2019, the sample Bustan in the study was a balance sheet report and a income statement period of 2017-2019. The type of data used in this research is the quantitative data of data obtained from PT. Garudafood, Tbk which in the form of numbers, such as financial statements, data collection techniques conducted are the study of documentation and library studies, then the data obtained is analyzed using three financial ratios namely, liquidity ratio, solvency ratio and profitability ratio. The indicators used in the analysis of financial ratios include current ratio, quick ratio, debt to total assets, debt to equity ratio, net profit margin and return on equity. Next to the Furthermore to measure the company's financial performance level using the financial ratio indicator.

Based on the results of the research that has been done that the financial performance of PT. Garudafood, Tbk measured using the liquidity ratio showed an increase over the last 3 years, to the ratio of solvency has not been safe performance because for the last 3 years has a value above $100 \%$, while the ratio of profitability for 3 years has not experienced even increased in the 40 value of So it can be said only the ratio of liquidity increased while the ratio of solvency and profitability ratio still have less good performance.
\end{abstract}

Keywords: financial performance, Garudafood

\section{Pendahuluan}

Industri dipilih karena memegang peranan penting dalam memenuhi kebutuhan konsumen banyak contoh industri makanan dan minuman seperti PT. Indofood CBP Sukses Makmur Tbk, PT. Ultra Jaya Milk Industry dan Tranding Company Tbk dan PT. Mayora yang memproduksi makanan bahkan minuman dalam judul skripsi yang saya buat memilih PT. Garuda Food Tbk karena bergerak dalam bidang industri makanan ringan terutama produk - produk dari kacang, coklat dan biskuit serta pengolahan susu pada saat ini kegiatan perusahaan dalam bidang industri makanan dan minuman PT. GarudaFood saat ini telah melakukan penjualan exspor ke lebih dari 20 negara dengan fokus ke pada negara - negara ASEAN, Dengan demikian, analisis kinerja keuangan beberapa perusahaan khususnya di industry makanan dan minuman (food and beverage) sangat penting untuk melihat kinerja keuangan beberapa perusahaan yang ada di BEI sehingga penulis tertarik untuk membahas mengenai : "Analisis Kinerja Keuangan PT Garuda Food ". Berdasarkan latar belakang penelitian yang telah diuraikan diatas maka permasalahan dalam penelitian ini dapat diidentifikasikan sebagai berikut: "Bagaimana kinerja keuangan perusahaan PT. GarudaFood?”

\section{Tinjauan Literatur}

\subsection{Analisis Kinerja Keuangan}

Fahmi (2012:2) dalam pongoh (2013:672) menyatakan kinerja keuangan adalah suatu analisis yang dilakukan untuk melihat sejauh mana suatu perusahaan telah melaksankan 
dengan menggunkan aturan-aturan pelaksanaan keuangan dengan baik dan benar. Seperti dengan membuat suatu laporan keuangan yang telah menjadi memenuhi standart dan ketentuan dalam SAK (Standar Akuntansi Keuangan) atau GAAP (General Accountinf Priciple) dan lainya. Sedangkan menurut (Harahap, 2016) kinerja keuangan merupakan hasil atau prestasi yang telah dicapi oleh manajemen perusahaan dalam menjalankan fungsinya mengelola aset perusahan secara efektif selama periode tertentu. Kinerja keuangan perusahaan merupakan salah satu faktor yang dilihat calon investor untuk menentukan investasi saham. Kinerja keuangan dapat dinilai dengan menggunkan beberapa alat analisis, salah satunya yakni analisis rasio keuangan.

\subsection{Hubungan Rasio dengan Kinerja Keuangan}

Menurut Fahmi (2012) dalam pongoh (2013) rasio keuanga dan kinerja perusahaan mempunyai hubungan yang erat. Rasio keuangan sangat banyak jumlahnnya dan setiap raiso ity mempunyai kegunaannya masing-masing bagi investor dia akan melihat rasio dengan penggunaan yang paling sesuai dengan analisis yang akan ia lakukan jika rasio tersebut tidak mempresentasikan tujuan dari analisis yang akan ia lakukan mka rasio rersebut didak digunakan. Karena dalam konsep keungan dengan konsep fleksibilitas artinya rumus atau berbagai bentuk formal yang dipergunakan harus disesuaikan dengan kasus yang diteliti.

\section{Metode Penelitian}

Kinerja keuangan yang diteliti dan dianalisis berdasarkan data laporan keuangan PT. Garudafood Tbk selama tiga tahun yaitu tahun 2017-2019 dalam laporan posisi keuangan PT. Garuda food Tbk yang telah dipublikasikan www.idx.co.id. Data yang digunakan adalah data laporan keuangan dari neraca dan laporan laba rugi PT. Garudafood, Tbk.Analisis kinerja keuangan PT. Garuda food Tbk dilihat dari analisis rasio keuangan.

Analisis data sangat diperlukan untuk pengujian hipotesis ini. Karena analisis ini bertujuan untuk menjawab hipotesis yang ada dalam penelitian ini dalam rangka menyelesaikan masalah dari penelitian ini, maka metode yang digunakan dalam penelitian ini adalah deskriptif. (Sugiyono, 2018) menyebutkan bahwa teknik analisis data dalam penelitian kuantitatif menggunakan statistik, dalam penelitian ini analisis data akan menggunakan teknik analisis statistik deskriptif. Menurut Fauzi, Dencik dan Asiati (2019). statistik deskriptif adalah statistik yang digunkan dalam menganalisa data dengan cara mendeskripsikan atau menggambarkan data yang telah terkumpul sebagaimana adanya tanpa bermaksud membuat kesimpulan yang berlaku untuk umum atau generalisasi. Penelitian deskriptif yaitu penelitian yang dilakukan untuk mengetahui nilai variabel mandiri, baik satu variabel atau lebih (independen) tanpa membuat perbandingan atau menghubungkan antara satu atau lebih variabel dengan variabel lainnya (Sugiyono, 2011).

\section{Hasil dan Pembahasan}

Tabel 1. Rata-Rata Rasio Keuangan PT Garudafood 2017-2019

\begin{tabular}{|c|l|c|c|c|c|}
\hline Keterangan & Indikator & $\mathbf{2 0 1 7}$ & $\mathbf{2 0 1 8}$ & $\mathbf{2 0 1 9}$ & Rata-rata \\
\hline \multirow{2}{*}{ Rasio Likuiditas } & $\begin{array}{l}\text { Current } \\
\text { ratio }\end{array}$ & $99,37 \%$ & $118,25 \%$ & $153,38 \%$ & $123,67 \%$ \\
\cline { 2 - 6 } & Quick ratio & $51,52 \%$ & $57,21 \%$ & $91,65 \%$ & $66,79 \%$ \\
\hline
\end{tabular}




\begin{tabular}{|c|c|c|c|c|c|}
\hline \multirow{3}{*}{ Rasio Solvabilitas } & $\begin{array}{l}\text { Debt to total } \\
\text { asset }\end{array}$ & $64,67 \%$ & $40,90 \%$ & $45,45 \%$ & $50,34 \%$ \\
\hline & $\begin{array}{l}\text { Debt to } \\
\text { equity ratio }\end{array}$ & $183,06 \%$ & $69,21 \%$ & $83,08 \%$ & $111,78 \%$ \\
\hline & $\begin{array}{lr}\text { Long } & \text { term } \\
\text { debt } & \text { to } \\
\text { equity } & \text { ratio }\end{array}$ & - & - & - & \\
\hline \multirow{4}{*}{$\begin{array}{c}\text { Rasio } \\
\text { Profitabilitas }\end{array}$} & $\begin{array}{l}\text { Gross profit } \\
\text { margin }\end{array}$ & - & - & - & \\
\hline & $\begin{array}{l}\text { Net profit } \\
\text { margin }\end{array}$ & $4,78 \%$ & $5,29 \%$ & $4,84 \%$ & $4,97 \%$ \\
\hline & $\begin{array}{l}\text { Return on } \\
\text { equity }\end{array}$ & $33,49 \%$ & $18,23 \%$ & $16,75 \%$ & $22,82 \%$ \\
\hline & $\begin{array}{l}\text { Return on } \\
\text { investment }\end{array}$ & - & - & - & \\
\hline
\end{tabular}

Berdasarkan tabel 4.5 diatas tentang rasio keuangan yang telah ditentukan pada penelitian ini yaitu rasio likuiditas, rasio solvabilitas dan rasio profitabilitas. Untuk rasio likuiditas yang diukur dengan current ratio dan quick ratio menunjukkan peningkatan kinerja rasio likuiditas selama 3 tahun terakhir yaitu dari tahun 2017 sampai tahun 2019 dimana current ratio memiliki rata-rata sebesar $123,67 \%$ dan quick ratio memiliki rata-rata sebesar $66,79 \%$ dimana jumlah aktiva lancar selama 3 tahun terakhir lebih tinggi jika dibandingkan hutang lancar sehingga rasio ini terus mengalami peningkatan kinerja selama 3 tahun terakhir.

Untuk rasio solvabilitas selama 3 tahun terakhir yang diukur menggunakan debt to total assets dan debt to equity ratio mengalami peningkatan kinerja meskipun angka persentase mengalami penurunan, karena pada rasio solvabilitas hasil yang semakin kecil semakin baik. Dimana pada debt to total asset selama 3 tahun terakhir memiliki nilai sebesar $50,34 \%$ yang berarti hasil ini masih terbilang aman karena masih dibawah $100 \%$. Sedangkan untuk debt to equity ratio selama tiga tahun terakhir juga mengalami peningkatan kinerja, dimana selama 3 tahun terakhir nilainya terus mengecil namun rasio ini belum dikatakan aman bagi PT Garudafood karena masih memiliki rata-rata selama 3 tahun terakhir sebesar $111,78 \%$ yang berarti bahwa total hutang masih 1,1 kali jika dibandingkan total modal.

Pada rasio profitabilitas perusahaan PT Garuda food selama 3 tahun terakhir yang diukur dengan net profit margin dan return on equity menunjukkan bahwa pada net profit margin selama 3 tahun terakhir hanya memiliki rata-rata 4,97\% meskipun memiliki nilai yang positif nilai ini terbilang cukup kecil bagi ukuran perusahaan publik yang hanya memiliki NPM tersebut. Sedangkan untuk return on equity selama 3 tahun terakhir memiliki ratarata sebesar 22,28\% diaman ROE tersebut mengalami penururunan kinerja selama 3 tahun terakhir dan hanya memiliki rata-rata sebesar itu. Dapat dikatakan bahwa rasio profitabilitas PT Garudafood belum dalam kondisi baik karena standar dari rasio profitabiltas perusahaan industri minimal $40 \%$.

\section{Kesimpulan}

Analisis yang dilakukan dalam penelitian ini menggunakan rasio-rasio keuangan yang 
telah ditentukan dalam penelitian ini yang terdiri dari rasio likuiditas (current ratio dan quick ratio), rasio solvabilitas (debt to total assets dan debt to equity ratio) dan rasio profitabilitas ( net profit margin dan return on equity). Penilaian kinerja perusahaan dilihat dari kemampuan perusahaan sesuai dari indikator yang telah ditentukan dalam penelitian ini.

Berdasarkan hasil penelitian yang telah dilakukan berdasarkan indikator yang telah ditentukan, bahwa kinerja PT Garuda Food selama 3 tahun terakhir yang ditinjau dari rasio likuiditas dan rasio solvabilitas memiliki kinerja yang baik karena mengalami peningkatan setiap tahunnya dan memenuhi kriteria sesuai indikator kinerja perusahaan. Dimana rasio likuiditas setiap tahunnya semakin besar, untuk rasio solvabilitas dimana tingkat rasionya semakin kecil setiap tahunnya yang berarti semakin baik karena tingkat menutupi hutang semakin cepat. Sedangkan untuk rasio profitabilitas terbilang kurang bagus karena memiliki nilai dibawah $40 \%$ yaitu angka dibawah standar industri dan setiap tahunnya untuk ROE mengalami penurunan karena penggunaan modal yang terus .

Berdasarkan hasil penelitian diatas, maka penulis akan memberikan beberapa saran sebagai berikut : (1) Bagi peneliti yang akan datang hendaknya menambahkan beberapa variabel perusahaan maupun rasio-rasio lainnya, sehingga dapat menjadi acuan penilaian yang lebih komprehensif. Selain itu juga peneliti selanjutnya disarankan untuk menambah periode waktu laporan keuangan perusahaan maupun menambah jumlah sampel perusahaan sehingga bisa melihat secara lebih jelas dampak yang diperoleh perusahaan, baik jangka pendek maupun jangka panjang; (2) Bagi manajemen perusahaan sebaiknya juga melakukan edukasi terhadap karyawannya mengenai peningkatan profitabilitas perusahaan serta dampak yang mungkin bisa diperoleh oleh perusahaan dan juga karyawan, sehingga karyawan bisa ikut serta dalam meningkatkan kinerja perusahaan. Hal ini diperlukan karena dilihat dari hasil penelitian, tidak semua rasio keuangan menghasilkan hasil yang sama.

\section{Referensi}

Asyikin, J., \& Tanu, V. S. (2011). Analisis Perbandingan Kinerja Keuangan Antara Perusahaan Farmasi Milik Pemerintah (Bumn) Dengan Perusahaan Farmasi Swasta Yang Terdaftar Di Bursa Efek Indonesia. Jurnal Spread, 1(1), 36-48.

Bambang, R. (2010). Dasar-Dasar Pembelanjaan Perusahaan (4th Ed.). Yogyakarta.

Fahmi, I. (2014). Analisis Kinerja Keuangan. Bandung: Alfabeta.

Fajrin, P. H., \& Laily, N. (2016). Analisis Profitabilitas Dan Likuiditas Terhadap Kinerja Keuangan Pt. Indofood Sukses Makmur, Tbk. Jurnal Ilmu Dan Riset Manajemen, 5(6), 18.

Fauzi, f., Dencik, A. B., \& Diah, I. A. (2019). Metodologi Penelitian untuk Manajemen dan Akuntansi. Jakarta: Salemba Empat.

Harahap, S. S. (2016). Analisis Kritis Atas Laporan Keuangan (Jakarta). Pt. Raja Grafindo Persada.

Hery. (2014). Akutansi Dasar 1 Dan 2. Jakarta: Kompas Gramedia.

Kasmir. (2012). Analisis Laporan Keuangan. Jakarta: Pt. Raja Grafindo Persada.

Kaunang, S. A. (2013). Analisis Kinerja Keuangan Perusahaan Pada Pt. Cipta Daya 
Nusatara Manado. Jurnal Emba, 1(4), 1993-2003. Https://Doi.Org/2300-117

Lustiyana, M., Sudjana, N., \& Husaini, A. (2016). Penggunaan Analisis Rasio Keuangan Untuk Menilai Kinerja Keuangan Perusahaan ( Studi Pada Pt. Semen Indonesia ( Persero), Tbk Periode 2012-2014). Jurnal Administrasi Bisnis S1 Universitas Brawijaya, 37(1), 121-128.

Munawir, S. (2010). Analisis Laporan Keuangan Edisi Keempat (15th Ed.). Yogyakarta: Liberty.

Pongoh, M. (2015). Analisis Laporan Keuangan Untuk Menilai Kinerja Keuangan Pt.

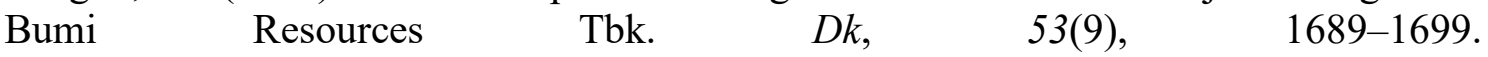
Https://Doi.Org/10.1017/Cbo9781107415324.004

Rambe, S. (2015). Analisis Pengaruh Corporate Social Responsibility, Profitabilitas Dan Ukuran Perusahaan Terhadap Nilai Perusahaan Pada Perusahaan Perkebunan Yang Go Public Di Indonesia, Malaysia, Dan Singapura.

Sartono, A. (2010). Manajemen Keuangan Teori Dan Aplikasi. Yogyakarta: Bpfe.

Sugiyono. (2018). Metode Penelitian Kuantitatif. Bandung: Alfabeta.

Zanara, M. (2012). Analisis Kinerja Keuangan Pada Pt Indosat Tbk (Ditinjau Dari Profitabilitas dan Likuiditas).

\section{Copyrights}

Copyright for this article is retained by the author(s), with first publication rights granted to the journal.

This is an open-access article distributed under the terms and conditions of the Creative Commons Attribution license (http://creativecommons.org/licenses/by/4.0/) 